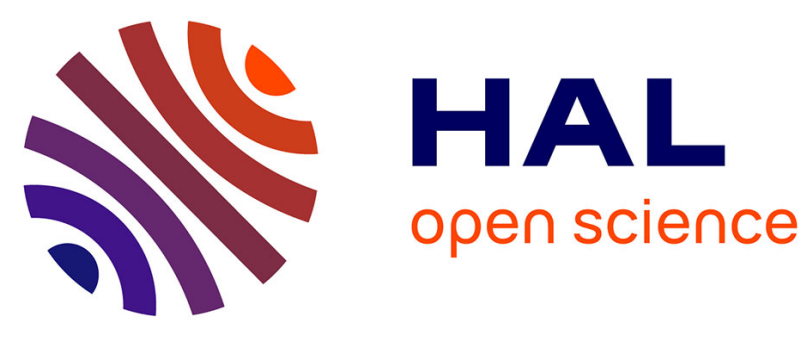

\title{
Fires and human activities as key factors in the high diversity of Corsican vegetation
}

Marion Lestienne, Isabelle Jouffroy-Bapicot, Déborah Leyssenne, Pierre Sabatier, Maxime Debret, Pierre-Jean Albertini, Danièle Colombaroli, Julien Didier, Christelle Hély, Boris Vannière

\section{To cite this version:}

Marion Lestienne, Isabelle Jouffroy-Bapicot, Déborah Leyssenne, Pierre Sabatier, Maxime Debret, et al.. Fires and human activities as key factors in the high diversity of Corsican vegetation. The Holocene, 2020, 30, pp.244-257. 10.1177/0959683619883025 . hal-02378546

\section{HAL Id: hal-02378546 https://hal.science/hal-02378546}

Submitted on 27 Nov 2019

HAL is a multi-disciplinary open access archive for the deposit and dissemination of scientific research documents, whether they are published or not. The documents may come from teaching and research institutions in France or abroad, or from public or private research centers.
L'archive ouverte pluridisciplinaire HAL, est destinée au dépôt et à la diffusion de documents scientifiques de niveau recherche, publiés ou non, émanant des établissements d'enseignement et de recherche français ou étrangers, des laboratoires publics ou privés. 


\title{
Fires and human activities as key factors in the high diversity of Corsican vegetation
}

\author{
Marion Lestienne, 1,2 (D) Isabelle Jouffroy-Bapicot,' \\ Déborah Leyssenne,' Pierre Sabatier, ${ }^{3}$ Maxime Debret, ${ }^{4}$ \\ Pierre-Jean Albertini, ${ }^{5}$ Daniele Colombaroli, ${ }^{6}$ Julien Didier, ${ }^{1}$ \\ Christelle Hély,7 and Boris Vannière ${ }^{1,8}$
}

\begin{abstract}
In the Mediterranean region, Corsica represents one of the most important hotspots of biodiversity, partly due to the high number of endemics species. This region is also one of the most affected by forest fires worldwide. The present vegetation is adapted to a wide range of disturbance regimes, but a change in fire frequency or intensity in the future may severely affect ecological resources and other socio-economical aspects. Here, we study the dynamics of vegetation-human-fire interactions for the past 12,000 years as recorded by Lake Bastani (Corsica, France). We used well-dated sedimentary records of charcoal, pollen and fungal spores to infer past fire regime, land cover and pastoral activities, respectively, and we compared our results with charcoal records from two other Corsican lakes (Nino and Creno, respectively). Our results suggest that climate and natural fires were the main factors shaping the landscape before $5000 \mathrm{cal}$. BP. Then, the extraordinary diversity of the current Corsican vegetation has been mainly promoted by human activities on the island (i.e. deforestation and pastoralism) at least from the Bronze Age ( 3500 cal. BP). The top of our record shows a sharp decrease in fungal remains (Sporormiella-type), usually associated with pastoral activities, which could be attributed to the land abandonment occurring since a few decades.
\end{abstract}

\section{Keywords}

Mediterranean, Holocene, Corsica, pollen, charcoal, fungal spores, pastoralism, deforestation, biodiversity

Received 8 March 2019; revised manuscript accepted 26 August 2019

\section{Introduction}

Mediterranean climate regions represent less than $5 \%$ of the Earth's surface, but host almost $20 \%$ of the world plant species (Cowling et al., 1996; Quezel, 1999). Located on a latitudinal gradient between temperate European ecosystems and semi-arid/ desert subtropical conditions of North Africa, the Mediterranean basin is characterized by a warm and dry summer season (Pausas, 2004; Sá et al., 2017), making it a fire-prone region (Keeley, 2009; Mouillot et al., 2002, 2003). Within this region, Corsica, belonging to the Tyrrhenian Islands, is well known for its biodiversity values, partly due to the high number of endemic species (Médail, 2017; Médail and Verlaque, 1997), making it one of the best preserved Mediterranean forest ecosystems (Medail and Quezel, 1997; Vogiatzakis et al., 2016). For these reasons, it is one of the most susceptible areas to climate and disturbanceregime changes (Giannakopoulos et al., 2005; Giorgi, 2006; Vogiatzakis et al., 2016). Currently, we are witnessing an agropastoral land abandonment of most the mountain areas of the island (Mouillot et al., 2005; San Roman Sanz et al., 2013). Moreover, a global increase in temperature and drought is predicted in the next decades (Giorgi, 2006; Giorgi and Lionello, 2008; Moriondo et al., 2006; Pausas, 2004). So we can expect an alteration of future fire regime and impacts on biodiversity (Colombaroli and Tinner, 2013; Pausas, 2004; Pausas and Fernández-Muñoz, 2012; Piñol et al., 1998), even if Corsican ecosystems seem well adapted to fire (Leys et al., 2014, 2018; Mouillot et al., 2008). Indeed, these ecosystems result from a long history of interactions between fire, land use and vegetation under variable climate conditions (Carcaillet et al., 2007; Leys, 2012; Leys et al., 2013). However, these interactions are still debated in Corsica and more generally at the regional scale (e.g. Carcaillet et al., 2007; Colombaroli and Tinner, 2013; Colombaroli et al., 2009; Vannière et al., 2016, 2011), and would deserve more studies fed by robust long-term datasets.

In this study, we will try to answer the following questions: How can we explain the Corsican vegetation composition? Can we observe different fire regimes during the Holocene? Are they linked with a particular vegetation pattern? What is the role of

'Chrono-Environnement, CNRS, Université Bourgogne Franche-Comté, Besançon, France

2ISEM, Université Montpellier, CNRS, EPHE, IRD, Montpellier, France ${ }^{3}$ Université Grenoble Alpes, Université Savoie Mont Blanc, CNRS, EDYTEM, Chambéry, France

${ }^{4}$ Laboratoire de Morphodynamique Continentale et Côtière, UMR 6143, Université de Rouen, Mont-Saint-Aignan, France

${ }^{5}$ Collectivité territoriale de Corse, Assemblée de Corse, Ajaccio, France ${ }^{6}$ Department of Geography, Royal Holloway, University of London, Egham, UK

${ }^{7}$ EPHE, PSL University, Paris, France

8MSHE Ledoux, CNRS, Université Bourgogne Franche-Comté,

Besançon, France

\section{Corresponding author:}

Marion Lestienne, Chrono-Environnement, CNRS, Université Bourgogne Franche-Comté, 16 route de gray, Besançon 25030, France. Email: marion.lestienne@umontpellier.fr 
humans in driving the ecological dynamics? Palaeoecological studies are great tools to answer these questions by permitting the reconstruction of past plant assemblages, fire regimes and human presence, and in order to study their relationship on the long-term socio-ecological trajectories (e.g. Colombaroli et al., 2007, 2008; Lestienne et al., 2017; Vannière et al., 2008).

Reille et al. (1992b, 1999) have been the first to reconstruct the Holocene Corsican vegetation from the Creno Lake sediment record in particular and a few other peat sequences. They highlighted the dominance of Pinus and Erica arborea in the early Holocene, followed by a significant change during the Neolithic, notably with an increase in Quercus ilex-type and Quercus pubescens-type, which thereafter dominated regional vegetation during most of the Holocene. These authors assumed that changes in climate and possibly fire regime could explain these vegetation changes. Carcaillet et al. (1997) used pedoanthracology to highlight the link between fire and the arrival of Quercus ilex in Corsica. These studies were precursors for Corsican history but they suffered from a lack of precise chronology. Later, Leys et al. (2014) investigated once more Lake Creno in order to reconstruct past fires and vegetation using charcoal (local to regional scale) and macro-remains (local scale). This study based on well-dated cores focused on Pinus nigra ssp. laricio (endemic Corsican species) expansion and demonstrated the presence of this pine during all the Holocene, often combined with deciduous broadleaf trees. Today, we propose to document the human impact on Corsican vegetation and fire regime to complete this history of the island. Moreover, no study has ever looked for the biodiversity dynamics in Corsica for the entire Holocene. While conservation problematics are more and more important worldwide, and particularly in the biodiversity hotspots like Corsica, we propose to reconstruct Corsican plant biodiversity dynamics.

This study focuses therefore on the vegetation diversity, human practices, fire regimes and their interactions in the past 12,000 years in Corsica. For these, we used a high-resolution and well-dated sedimentary record from Bastani Lake, which is a 2000-m elevation water body well located to capture a regional signal. Bastani Lake is a key study site for Corsica because (1) it is a good candidate to capture a signal at the landscape scale due to its high elevation, very restricted watershed and its windward exposure to strong winds (Conchon, 1988; Roche and Loye-Pilot, 1989 ) and (2) its sedimentation rate is almost constant and the chronology covers all the Holocene. This study is also based on a multiproxy approach (charcoal, pollen, fungal remains) in order to reconstruct biomass burning, land cover dynamics and land use history of the Monte Renoso area. In addition, we have used an innovative method of charcoal morphologies calculation. We will discuss the interest of using such method for advancing palaeoenvironmental inferences.

Because fire has been a major driving force in the Mediterranean region since the emergence of the Mediterranean climate (Médail, 2017), we hypothesize that fires could be one of the factors favouring the maintenance of the high biodiversity characterizing the Mediterranean region.

Our data contribute to the global Mediterranean fire knowledge by providing a new quantitative and high-resolution series from a key region in the Central Mediterranean region.

\section{Materials and methods}

\section{Study area}

Lake Bastani $\left(42^{\circ} 30^{\prime} \mathrm{N}, 9^{\circ} 80^{\prime} \mathrm{E}\right)$ is located in Corsica (France), in front of the Monte Renoso mountain, and is one of the highest lakes in the island (Figure 1a). This lake covers $43,800 \mathrm{~m}^{2}$ with a maximum depth of $24 \mathrm{~m}$ and has a restricted watershed of $173,000 \mathrm{~m}^{2}$, mainly composed of granodiorite, containing no permanent streams and delivering very limited local lithogenic input to the lake sediment (BRGM, 2009). It formed behind a glacial cirque dammed by moraine abandoned by the glacier in the late-Glacial period (14,000 cal. BP) (Gauthier et al., 1984). Due to the topography, this windward lake is a good captor for wind-transport particles including pollen and charcoals produced in the surrounding regional area (Conchon, 1988; Roche and Loye-Pilot, 1989). It lies at the boundary between the subalpine and alpine vegetation belts (Figure 1b), and is characterized by cold winter and mild summer (Gamisans, 1999). Grasslands and low shrubby formations of Alnus viridis subs. suaveolens, Juniperus and Berberis compose the surrounding vegetation. Further down in the valley, more and more dense mixed oak forest is composed of Quercus ilex, Quercus pubescens, Pinus nigra, Erica arborea and Arbutus unedo (Figure 1b and c) (Gauthier et al., 1983; Reille et al., 1999, 1997)

\section{Core extraction and dating}

The lacustrine sediment cores were extracted from a floating platform using a UWITEC gravity corer. Two core sections composed the whole record sequence $(183 \mathrm{~cm})$ called BAS15-MC (Table 1). The chronological control was based on a combination of (1) 10 radiocarbon dates obtained at the Poznan Radiocarbon Laboratory on diverse macro-remains of terrestrial origin (leaves, seeds, charcoals and wood), (2) one age estimated for the main late-Glacial/early Holocene transitions indicated by the pollen stratigraphy and the geochemistry data and (3) 2 radiometric markers derived from short-lived radionuclides $(210 \mathrm{~Pb}, 137 \mathrm{Cs})$ for the top of the core. Based on these chronological markers, Clam package (R software, R. RCore and Team, 2018) has been used to generate an age depth model (Table 1) within a $95 \%$ confidence limit (Blaauw, 2010).

\section{Charcoal analysis}

A total of 271 contiguous sediment samples were retrieved along core BAS15-MC each 10 or $5 \mathrm{~mm}$ (depending of the sedimentation rate). For charcoal extraction, each sample was washed on an 80- $\mu \mathrm{m}$ mesh sieve after hydrochloric acid and hydrogen peroxide treatments according to the standardized macro-charcoal sieving method (N and Rhodes, 1998; Whitlock and Larsen, 2002).

All charcoal particles from each sample have been observed with a digital microscope coupled to the high-speed camera Keyence VHX-5000. Images, observed using a 100-magnification, have been assembled to observe the entire sample on one picture with a high precision. From this picture, and adding information on charcoal visual characteristics (colour and brightness ranges), the microscope software performs a semi-automated counting of charcoal particles present in the sample: each particle corresponding to the colour and brightness ranges chosen are selected and the user visually checks each particle. The Keyence VHX-5000 software also measures the length, width, area and perimeter of each selected particle.

The charcoal record was quantified calculating the CHarcoal Accumulation Rates (CHAR), that is, the quantity of charcoal particles per volume of sediment and per unit of time according to the sedimentation accumulation rate estimated by the depth-age model. Charcoal quantity has been estimated using either the number of charcoal particles per area unit and time unit ('CHARnb': \#/cm²/yr), or the total area of charcoal particles per area unit per time unit ('CHARar': $\mu \mathrm{m}^{2} / \mathrm{cm}^{2} / \mathrm{yr}$ ). The comparison of these two metrics provides information about the mean charcoal particle size of each sample. Significant charcoal peaks have then been highlighted using the Char_Analysis software by subtracting the CHAR-background, which represents the variation in overall charcoal production, sedimentation, mixing and sampling, from the CHAR-series (Higuera, 2009). The morphology of charcoal particles has also been quantified to inform about the type of 

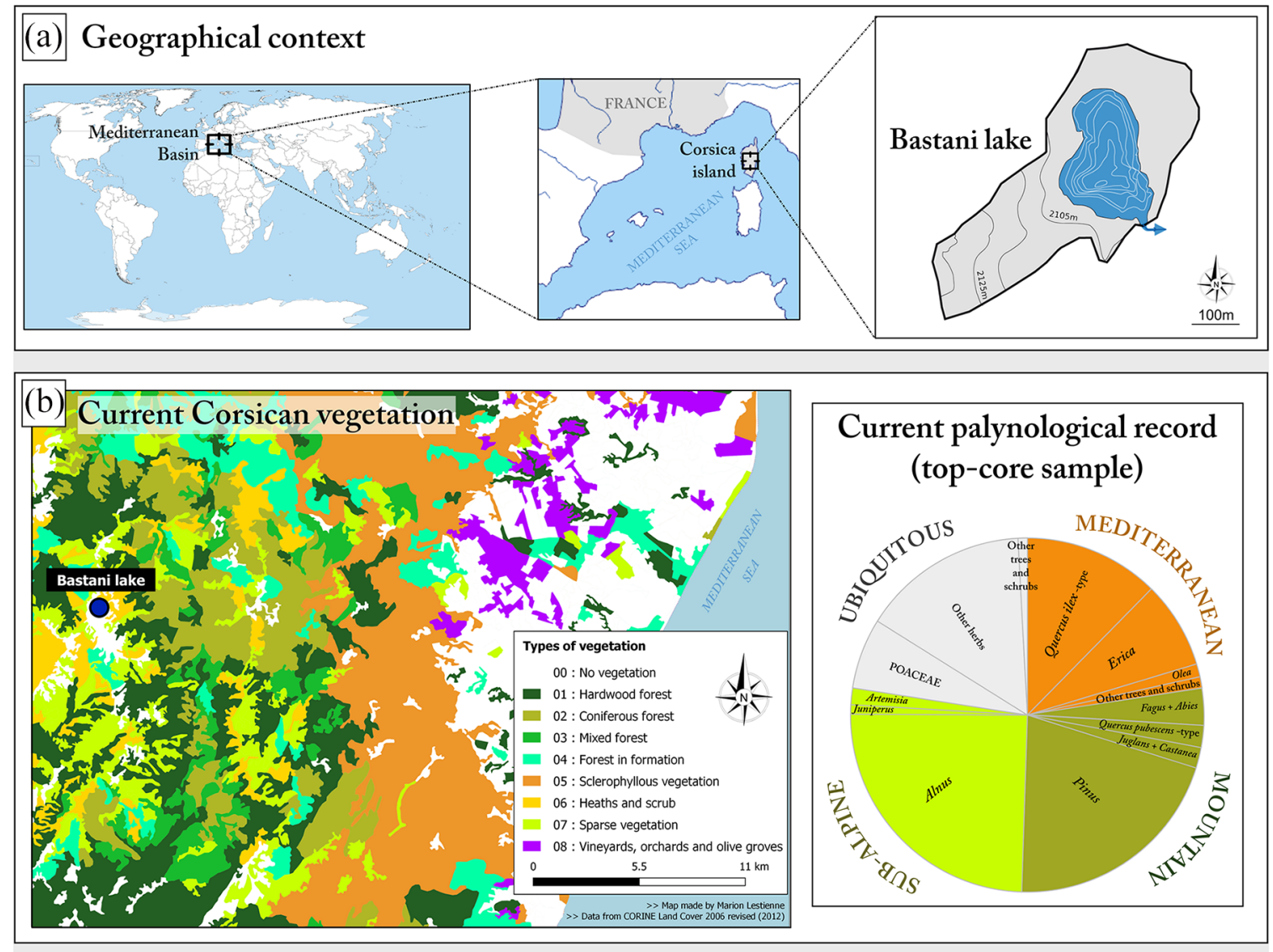

(c) Topography with dominant vegetation

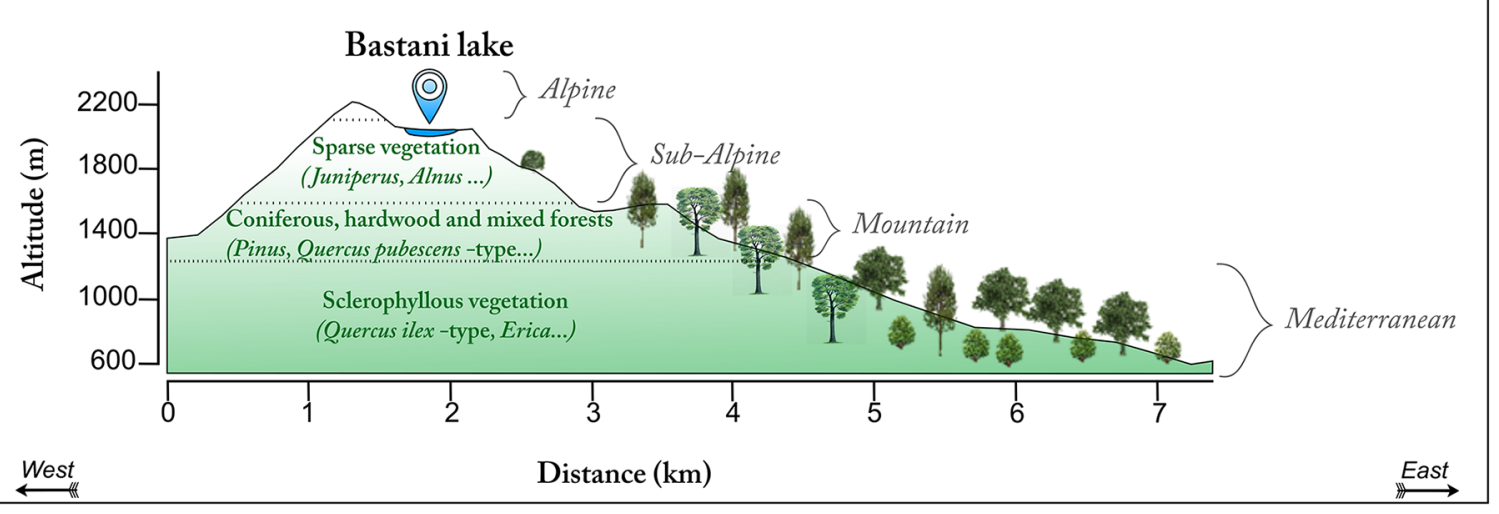

Figure I. Current context of the Lake Bastani region (Corsica, FR). (a) Geographical context of the lake Bastani. (b) Current surrounding vegetation (CNRS Ecolab and CORINE Land Cover 2006 revised (20I2)) and current palynological record (top-core sample). Map have been generated with the Quantum GIS software version 3.4.I. (c) Topographic section (https://www.geoportail.gouv.fr/) including the dominant vegetation.

Table I. List of core sections used for the Master Core of Bastani Lake sequence (BASI5-MC) and sub-sampling bins used for palaeoecological discrete analyses.

\begin{tabular}{lll}
\hline ID & Depth $(\mathrm{cm})$ & Sampling \\
\hline BASI5_PI & $8-23$ & Half-centimetric \\
BASI5_PI & $23-66$ & Centimetric \\
BASI5_P6 & $57-110$ & Centimetric \\
BASI5_P6 & $110-185$ & Half-centimetric \\
\hline
\end{tabular}

biomass burned (Enache and Cumming, 2006; Leys et al., 2017; Mustaphi and Pisaric, 2014; Umbanhowar and Megrath, 1998). In this study, we measured the commonly used normalized width versus length ratio (W/L). A positive ratio shows 'compact' particle, and a negative ratio shows an 'elongated' particle (Enache and Cumming, 2006). Using the high-precision microscope allowed

us to define a new proxy to describe the charcoal shape complexity by measuring the normalized area versus perimeter ratio $(\mathrm{A} / \mathrm{P})$. A positive ratio shows that the particle is 'geometric', and a negative ratio shows that the particle is 'indented'. Because these measures are rarely studied, a short synthesis, as exhaustive as possible, seemed to be appropriate to introduce our results.

The first meaningful study about the morphology of charcoal particles has been performed by Patterson et al. (1987). They studied the size of charcoal particles by comparing it with the potential distance that the particle could travel: the smaller the particle, the longer the distance it can travel from the place it was produced, adding the influence of the wind on the charcoal particles distribution. Moreover, the proximity of several fires can bias the observer. Later, it was shown that small particles reflect a regional signal whereas bigger particles reflect a more local 
signal (Clark and Royall, 1995). More recent studies (e.g. Ali et al., 2009; Carcaillet et al., 2001; Leys et al., 2013; Whitlock and Larsen, 2002) have suggested that the differences in charcoal sizes retrieved in sediments are mainly due to fire type (crown or surface fires) and taphonomical processes, including charcoal transportation.

In parallel, Umbanhowar and Mcgrath (1998) used the charcoal morphology as an indicator of the vegetation type in the Minnesota forests (USA). To quantify the different morphotypes, they used the width/length ratio and found that elongated particles (normalized ratio $<0$ ) would correspond to herbaceous fuels, when intermediate $\mathrm{W} / \mathrm{L}$ ratio would correspond to charcoal derived from leaves or wood. Since then, several authors added their contribution by developing classifications of the different charcoal morphologies. Among them, Jensen et al., (2007) defined five common charcoal morphotypes by comparing them with charcoals from prescribed burns of modern plant material. From this experience, they concluded that grass cuticles, conifer wood and leaves of some broadleaved taxa produce different and recognizable charcoal types. Similarly, Enache and Cumming (2007) defined seven distinct morphological types of charcoals. In contrast to the previous study, they assume that charcoal morphologies are related to the bio-geo-climatic and lake watershed characteristics and so they suggest that they can provide insights into past fire and climate. From these two founding studies, Mustaphi and Pisaric (2014) developed a new classification of 27 charcoal morphotypes. Beyond their conclusions, we can note that some morphotypes can easily be attributed to specific fuel. It is the case for elongated charcoals, which can correspond to grass, and for porous charcoals, which can correspond to needles, grass or leaves. Some morphotypes can also be used as an indicator of the kind of signal and/or of the kind of transport. For example, a morphotype that presents an indented shape and/or that is associated to fragile fuel as leaves can also reflect a local signal and a lower transport energy regime (Vannière et al., 2003).

\section{Pollen and fungal remains analysis}

In parallel to charcoal treatments, sedimentary samples were also prepared according to standard techniques for pollen analysis (Fægri and Iversen, 1989), including Lycopodium tablets addition for estimating pollen and fungal spore concentrations (grains/ $\mathrm{cm}^{3}$ ) and influx (grains/ $\mathrm{cm}^{2} /$ year; Stockmarr, 1971). Pollen grains were identified using keys, photographs (Reille, 1992a) and with reference to the modern pollen collection at the Chrono-environment Laboratory in Besançon. On the same slides as for pollen, algal and fungal remains, which were the main non-pollen palynomorphs, were identified and counted using the available literature (present-day ecology: Ellis and Ellis, 1986, palaeoecology; e.g. Van Geel, 2001, Van Cugny et al., 2010; Geel and Aptroot, 2006). Pollen and fern spores counting was performed using the Polycounter free software from Nakagawa (available online: http://polsystems.rits-palaeo.com/index.html\#PolyCounter). For a given sample, pollen grain counts stopped when both the diversity curve and the main taxa percentages stabilized (min count 520 and max count 2900). For the algal and fungal remains counting, a minimum count of 350 Lycopodium spores per sample was reached for the assessment of fungal spore concentration (Etienne and Jouffroy-Bapicot, 2014). Pollen percentages were based on the sum of dry-ground vascular plant pollen (i.e. total terrestrial pollen or total land pollen; TLP). Relative values of pollen were calculated as a percentage of the TLP sum (TLPS) using the Tilia software (ref), and the relative and influx diagrams were constructed with TGView (Grimm, 1991, 2004). The relative pollen patterns and the fungal remain assemblages were individually divided along the overall temporal sequence into significantly different periods using stratigraphic constrained cluster analysis, with the Tilia CONISS function (ref).

\section{Biodiversity analysis}

Redundancy analysis (RDA; Lepš and Šmilauer, 2003; Ter Braak and Smilauer, 2002) is a statistical procedure to express how much of the variance in one set of variables (response variables) can be explained by another set of variables (explanatory variables). Two environmental variables were included as possible explanatory factors for the pollen species composition. The first one is the charcoal influx as a fire proxy (e.g. Colombaroli et al., 2009). The second one is the Sporormiella-type fungal remain, which is one of the most reliable indicators of herbivory and the most used proxy of pastoral activities (Baker et al., 2013).

To assess the biodiversity changes in the lake surroundings, pollen diversity has been estimated using richness (Birks and Line, 1992) and evenness (Hurlbert, 1971) to encompass both diversity dimensions. Palynological richness corresponds to the expected number of taxa found in samples of equal size as estimated by rarefaction analysis. It is a robust method used in many palaeoecological studies, including the Mediterranean environments (Beffa et al., 2016; Colombaroli et al., 2007, 2009; Colombaroli and Tinner, 2013). It was achieved in this study using the Vegan package (Dixon, 2003) of the statistical software R (Venables et al., 2018) and a constant pollen sum, which was standardized on the minimum pollen sum $(n=520)$.

The probability of interspecific encounters (PIE) was used as an index of evenness (Hurlbert, 1971). This index gives the probability that two randomly sampled pollen grains from a given habitat type represent two different species, and it is calculated as follows:

$$
P I E=\left(\frac{N}{N-1}\right)\left(1-\sum_{i=1}^{s} p_{i}^{2}\right)
$$

where $N$ is the total number of taxa and $p$ is the frequency of each taxon in the assemblage.

Finally, the Spearman's rank-correlation (Spearman, 1904) was used to assess the covariation between biodiversity characteristics (i.e. richness, evenness) and environmental factors (fire and pasture). Only the main results from these analyses are presented in the 'Results' section. The detailed results are presented in the Supplementary Material (available online).

\section{Results}

\section{Age-depth model}

The sediment from BAS15-MC is composed of two units, the upper unit $(0-180 \mathrm{~cm})$ consists of olive-grey silty clay rich in organic content and a lower unit $(180-183 \mathrm{~cm})$ is formed of light grey clay with low organic content. The first unit presents two phases with higher organic content from 170 to $100 \mathrm{~cm}$ and over the last $5 \mathrm{~cm}$. The age-depth model obtained indicated that the Bastani Lake sediment record $(183 \mathrm{~cm})$ covers the entire Holocene (Figure 2). The oldest part is dated from 11,650 cal. BP. There is an average of 68 years on each centimetre (median is 79 years) for the whole Holocene. The unit change corresponds to the late-Glacial/Holocene transition. The accumulation rate is constant around $0.01 \mathrm{~cm} / \mathrm{yr}$ between the beginning of the Holocene and $1600 \mathrm{cal}$. BP. Between 1600 and $500 \mathrm{cal}$. BP, there is an accumulation rate increase from 0.01 to $0.06 \mathrm{~cm} / \mathrm{yr}$. Then it decreases until $0.03 \mathrm{~cm} / \mathrm{yr}$ between 500 and $150 \mathrm{cal}$. BP and increases again until reaching $0.05 \mathrm{~cm} / \mathrm{yr}$ nowadays.

\section{Pollen, fungal remains and charcoal dynamics}

Eight global zones have been highlighted on the basis of the local pollen zones and local fungal remains zones obtained with the CONISS cluster analysis and according to the CHAR signal (Figure 3 and Table 3). The details for each proxy and zone are 
presented in the Supplementary materials (II and III) available online.

Zone I (I2,000-II,500 cal. BP, i.e. the Palaeolithic period). The beginning of the Holocene was characterized by a sharp decrease in the herbaceous taxa curve, rising from $40 \%$ to $20 \%$ of the TLPS, mainly represented by Artemisia and a concomitant rise of arboreal pollen. Pinus widely dominated the woody taxa (from $55 \%$ of the pollen at the beginning to $85 \%$ at the end of the period). Some trees and/or shrubs were also present: Alnus all over the period, Juniperus at the beginning and Corylus at the end of the period. The quantity and diversity of fungal remains were low and Sporormiella-type was the only type represented all over the period. Charcoal influx values were very low without a significant charcoal peak.

Zone 2 (II,500-7500 cal. BP, i.e. the Mesolithic period). From 11,500 to 9500 cal. BP (2a), Pinus was largely dominant. From

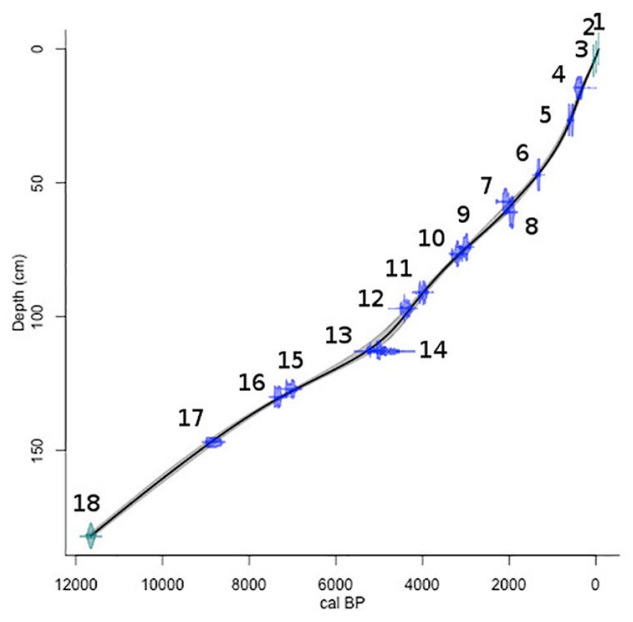

Figure 2. Age-depth model for Bastani Lake sequence. Details for each date are presented in Table 2.
$9500 \mathrm{cal}$. BP (2b), the relative proportion of trees and shrubs versus herbaceous did not change, but the percentages of Pinus dropped sharply to $40 \%$ of TLPS, while the percentages of Erica increased very rapidly up to $40 \%$. Other taxa remained stable. This period was also characterized by an increase in the charcoal signal and 18 significant charcoal peaks brought out, up to $1.5 \mathrm{\#} / \mathrm{cm}^{2} / \mathrm{yr}$ and $5000 \mu \mathrm{m}^{2} / \mathrm{cm}^{2} / \mathrm{yr}$. They accounted for $42 \%$ of the total number of peaks over the last 12,000 years. The most fire-prone period (i.e. high concentration of charcoal peaks) occurred between 11,000 and $10,000 \mathrm{cal}$. BP. The $\mathrm{W} / \mathrm{L}$ ratio of the charcoal particles stayed slightly higher than zero indicating compact charcoal particles. Similarly, the high A/P ratio was representative of geometric particles. Finally, the charcoal particle size was broadly small (CHARnb curve is higher than CHARar curve), while the fungal remains did not change.

Zone 3 (7500-6500 cal. BP, i.e. the early Neolithic period). Around 7500 cal. BP, Erica's curve displayed a dramatic and sustained decrease from $40 \%$ to $10 \%$ of the TLPS. Conversely, Pinus rose again up to $60 \%$. This period also marked a strong diversification of shrub species. The fungal remains assemblages were slightly more diversified (Xylariaceae/Coniochaetaceae from $7500 \mathrm{cal}$. BP onward). In the same time, the charcoal content declined and peaks were rare.

Zones 4 (6500-5000 cal. BP, i.e. the mid- to the late-Neolithic period). From 6500 cal. BP, Quercus ilex-type and Quercus pubescens-type rose together, while evergreen Quercus pollen was the most important type influencing the variation of the global curve of Quercus. Alnus stabilized around $10 \%$ and its local presence has been highlighted thanks to pollen clumps in the palynofacies, as for Poaceae that slightly increased as well. A slight but globally continuous increase in fungal remains was observed at the same period, especially the most dung-related fungi. The usually woodrelated types (Xylariaceae to Helicoon) were much more diversified and continuously present than before. Only one significant charcoal peak was recorded, and both CHARnb and CHARar decreased down to less than $0.5 \# / \mathrm{cm}^{2} / \mathrm{yr}$ and $5000 \mu \mathrm{m}^{2} / \mathrm{cm}^{2} / \mathrm{yr}$, respectively.

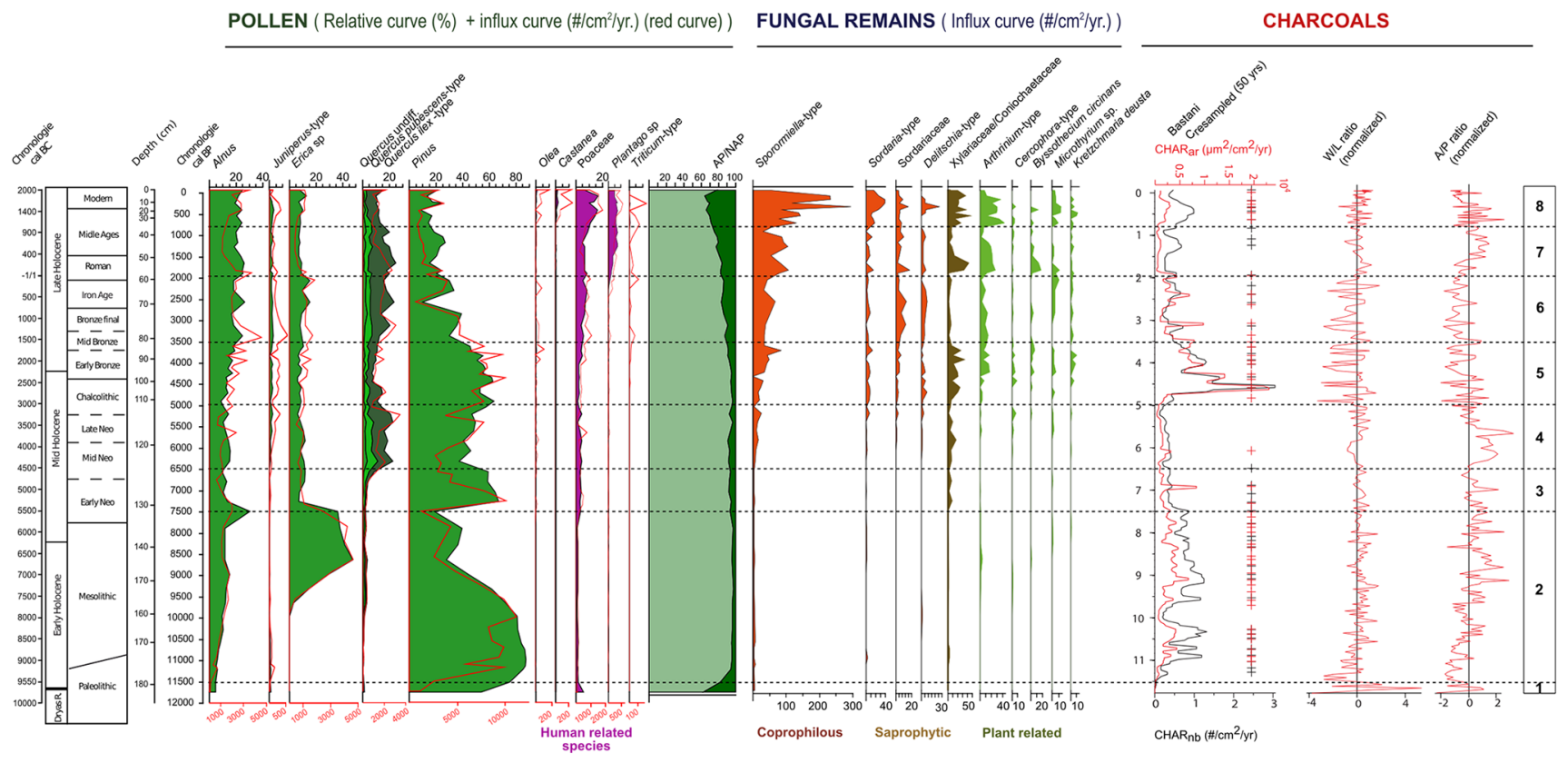

Figure 3. Age scaled diagram of pollen percentages, fungal spores and charcoal influx with indication of the main zones of the evolution. Pollen are represented as relative curves (\%). Fungal remains are represented as influx curves $\left(\# / \mathrm{cm}^{2} / \mathrm{yr}\right)$ ). Charcoal accumulation rates are presented both by the particle number (black curve; \#/ $\mathrm{cm}^{2} / \mathrm{yr}$ ) and the total particle area (red curve; $\mu \mathrm{m}^{2} / \mathrm{cm}^{2} / \mathrm{yr}$ ). Crosses highlight fire episodes marked by significant peaks detected with Charanalysis statistical treatment (Higuera et al., 2009). The normalized width/length (W/L) ratio and the normalized area/ perimeter (A/P) ratio of charcoal document change in particle shape. 
Table 2. $\mathrm{Pb} 210,{ }^{14} \mathrm{C}$ and pollen-inferred ages used for age-depth model of Bastani Lake sequence.

\begin{tabular}{|c|c|c|c|c|c|c|}
\hline & ID & Depth $(\mathrm{cm})$ & Lab code & ${ }^{14} \mathrm{C}$ yr BP & Yr BP & Dated material \\
\hline I & Top & 0 & & & -65 & \\
\hline 2 & CsI37 bomb & 3 & & & $-13 \pm 2$ & \\
\hline 3 & $210 \mathrm{~Pb}$ & 4.4 & & & $50 \pm 5$ & \\
\hline 4 & BASI3_PI-20 & 14.5 & Poz-69623 & $325 \pm 30$ & & Terrestrial macro-remains \\
\hline 5 & BASI3_PI-30 & 26.5 & Poz-69624 & $545 \pm 30$ & & Terrestrial macro-remains \\
\hline 6 & BASI3_PI-46 & 47 & Poz-73333 & $1410 \pm 30$ & & Terrestrial macro-remains \\
\hline 7 & BASI3_PI-55 & 57 & Poz-69625 & $2110 \pm 30$ & & Terrestrial macro-remains \\
\hline 8 & BASI5_P6-62 & 61 & Poz-9|245 & $1990 \pm 30$ & & Wood \\
\hline 9 & BASI5_P6-75 & 74 & Poz-91246 & $2875 \pm 30$ & & Wood \\
\hline 10 & BASI3_P4-102 & 76.5 & Poz-6II53 & $3000 \pm 35$ & & Terrestrial macro-remains \\
\hline II & BASI5_P6-92 & 91 & Poz-109519 & $3660 \pm 35$ & & Terrestrial macro-remains \\
\hline 12 & BASI5_P6-98 & 97 & Poz-9|247 & $3940 \pm 40$ & & Plant remains \\
\hline 13 & BASI5_P6-II 3.5 & 112.5 & Poz_909520 & $4430 \pm 35$ & & Terrestrial macro-remains \\
\hline 14 & BASI5_P6-II4 & 113 & Poz-96090 & $4280 \pm 120$ & & Charcoal \\
\hline 15 & BASI5_P6-I28 & 127 & Poz-9|248 & $6130 \pm 40$ & & Plant remains \\
\hline 16 & BASI5_P6-I3I & 130 & Poz-9609I & $6400 \pm 50$ & & Charcoal \\
\hline 17 & BASI5_P6-I48 & 147 & Poz-91249 & $7960 \pm 50$ & & Plant remains \\
\hline \multirow[t]{2}{*}{18} & BASI5_P6-I8| & 182 & & & 11,650 & \\
\hline & (Holocene pollen data) & & & & & \\
\hline
\end{tabular}

Table 3. Summary of the eight main periods of palaeoecological changes occurring in the Lake Bastani sequence.

\begin{tabular}{|c|c|c|c|c|c|c|}
\hline \multirow{2}{*}{ Main zones } & \multirow{2}{*}{$\begin{array}{l}\text { Age cal. BP } \\
12,000\end{array}$} & \multicolumn{2}{|c|}{ Local pollen zone } & \multicolumn{2}{|c|}{ Local fungal remains zone } & \multirow{2}{*}{$\begin{array}{l}\text { Local charcoals zone } \\
\text { Low CHARnb and CHARar. No significant } \\
\text { charcoal peaks }\end{array}$} \\
\hline & & la & $\begin{array}{l}\text { Very low diversity. Pinus is } \\
\text { dominant }\end{array}$ & $A$ & $\begin{array}{l}\text { Very low quantity and diversity. } \\
\text { Sporormiella sp. is dominant }\end{array}$ & \\
\hline 2 & 11,500 & $\mathrm{Ib}$ & $\begin{array}{l}\text { Pinus is still dominant, diver- } \\
\text { sity increases } \\
\text { Erica increases while Pinus } \\
\text { decreases }\end{array}$ & & & $\begin{array}{l}\text { Strong increase of CHARnb and CHARar. A } \\
\text { total of I } 8 \text { significant charcoal peaks. Small, } \\
\text { compact and geometric particles }\end{array}$ \\
\hline 3 & 7500 & $2 b$ & $\begin{array}{l}\text { Erica decreases while Pinus } \\
\text { increases. Shrubs are diver- } \\
\text { sifying }\end{array}$ & B & $\begin{array}{l}\text { As previous zone, but diversity } \\
\text { is increasing }\end{array}$ & $\begin{array}{l}\text { Decrease of CHARnb and CHARar. Only } \\
\text { one charcoal peak }\end{array}$ \\
\hline 4 & 6500 & $2 b^{\prime}$ & $\begin{array}{l}\text { Development of Quercus ilex- } \\
\text { type. Poaceae increase }\end{array}$ & $\mathrm{C}$ & $\begin{array}{l}\text { Strong increase of all taxa, } \\
\text { including dung-related fungi and } \\
\text { wood related taxa }\end{array}$ & \\
\hline 5 & 5000 & & & & $\begin{array}{l}\text { Small decrease between } 1250 \\
\text { and } 800 \text { cal. BP }\end{array}$ & Strong increase in CHARnb and CHARar \\
\hline 6 & 3500 & $3 a$ & $\begin{array}{l}\text { Decrease of Pinus and other } \\
\text { trees. Increase of herbaceous } \\
\text { and human related taxa }\end{array}$ & & & $\begin{array}{l}\text { I5 significant charcoal } \\
\text { peaks. Big, elongated and indented particles }\end{array}$ \\
\hline 7 & 1800 & $3 b$ & $\begin{array}{l}\text { Decrease of trees and } \\
\text { increase of herbs }\end{array}$ & & & $\begin{array}{l}\text { Decrease of CHARnb and CHARar. One } \\
\text { significant charcoal peak }\end{array}$ \\
\hline 8 & 800 & 4 & $\begin{array}{l}\text { Presence of typical } \\
\text { Mediterranean cultivated } \\
\text { species }\end{array}$ & D & $\begin{array}{l}\text { Strong increase of the quantity } \\
\text { and diversity of all taxa }\end{array}$ & $\begin{array}{l}\text { Increase of CHARnb and CHARar. Six sig- } \\
\text { nificant charcoal peaks. Very small, compact } \\
\text { and geometric particles }\end{array}$ \\
\hline
\end{tabular}

These zones have been highlighted on the basis of pollen zones and fungal remains zones obtained with the CONISS cluster analysis and on the CHARnb and CHARar variations (Figure 3). For detailed pollen and fungal remains diagram, see the Supplementary materials, available online.

Zone 5 (5000-3500 cal. BP, i.e. from the Chalcolithic to the Bronze Age). No significant changes were observed for pollen and fungal remains. Nevertheless, the CHARnb and CHARar strongly increased with nine significant peaks $(21 \%$ of the total number of peaks), especially just before $4500 \mathrm{cal}$. BP when the highest charcoal peak of the entire sequence was found $\left(>2 \# / \mathrm{cm}^{2} / \mathrm{yr}\right.$ and 20,000 $\mu \mathrm{m}^{2} / \mathrm{cm}^{2} / \mathrm{yr}$ ). The mean charcoal particle size increased (CHARnb values were lower than CHARar values), the W/L ratio decreased a lot, indicating that the charcoal particles were more elongated, and the $\mathrm{A} / \mathrm{P}$ ratio was low, suggesting indented shape.

Zones 6 (from 3500-1800 cal. BP, i.e. from the final Bronze Age to the Iron Age). The decrease in Pinus abundance drove an overall decrease in trees and shrubs, despite a slight increase in both evergreen Quercus and mountainous species (Abies and Fagus). The number of herbaceous taxa increased, especially Poaceae and human-related taxa such as crops (Hordeum-type, Triticumtype), and ruderals (Plantago-type, Rumex). The quantity of fungal remains significantly arose after 3500 cal. BP and Sporormiella sp. Delitchia sp., the Sordariales and Arthinium sp. were wellrepresented taxa. The charcoal signal stayed high with six significant peaks.

Zone 7 (from 1800 to $800 \mathrm{cal}$. BP, i.e. the Roman and Middle Ages). At this time, most of the trees and shrubs taxa maintained, except Quercus ilex-type, Quercus pubescens-type and Pinus, which decreased in favour of the herbs. The presence of the typical Mediterranean cultivated tree species (Olea, Juglans and 


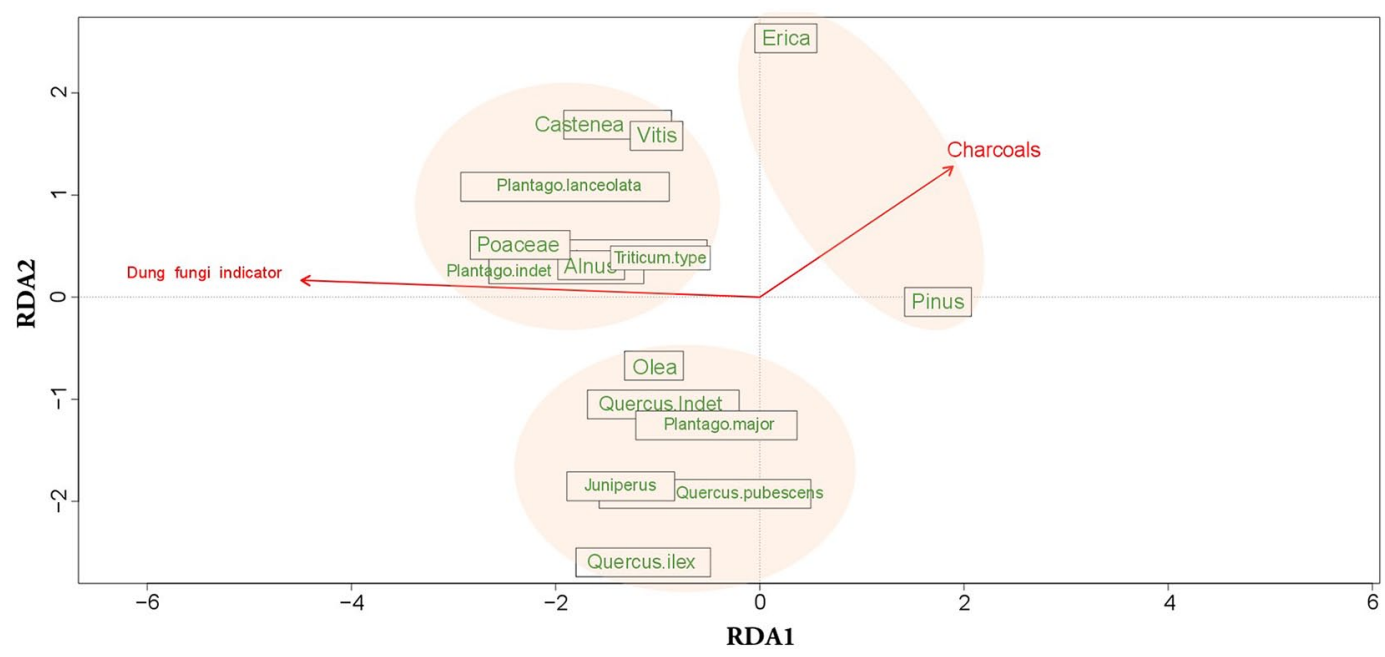

Figure 4. RDA biplot of the selected species and two explanatory variables: charcoal influx and spores of the dung fungus Sporormiella influx are used as proxies for fire (which influences $10.5 \%$ of data variance) and presence of grazing mammals (which influences $26.5 \%$ of data variance). Castanea, Alnus, Triticum and Poaceae, compose the first group, Erica and Pinus compose the second group, and Plantago, Junipeus, Quercus pubescens-type and Quercus ilex-type compose the last group.

Castanea) was more regular and their proportion more important. Between 1250 and $800 \mathrm{cal}$. BP a decrease in some of the main fungal remains types, especially Sporormiella sp. and Arthrinium sp. was part of a global decrease. The charcoal signal became very weak with only one significant charcoal peak at $c a$. 1400 cal. BP.

Zone 8 (after $800 \mathrm{cal}$. BP, i.e. from the Middle Age to the Modern times). No significant changes in the vegetation were observed, but the diversity and the quantity of fungal remains reached their maximum values during this last period, especially at its beginning. The best dung indicators types, namely Sporormiella $s p$. and Sordaria $s p$., were largely dominant. The charcoal signal also increased until reaching six significant peaks (more than $1 \# / \mathrm{cm}^{2} / \mathrm{yr}$ and $2500 \mu \mathrm{m}^{2} / \mathrm{cm}^{2} / \mathrm{yr}$ ) at about $500 \mathrm{cal}$. BP, then it decreased rapidly until almost zero. This period encompassed a new decrease in the $\mathrm{A} / \mathrm{P}$ ratio and an increase in the $\mathrm{W} / \mathrm{L}$ ratio, indicating more compact and geometric particles. In the same time, the mean particles size decreased and seemed to be smaller than the first period (the CHARar values were much lower while the CHARnb values are similar).

\section{Vegetation and biodiversity dynamics}

RDA with charcoal influx suggests that fire explains $10.5 \%$ of the vegetation dataset variance (Figure 4). Erica and Pinus taxa are positively correlated to charcoal influx, whereas Olea, Quercus, Plantago major/media and Juniperus are negatively correlated. Spores of dung fungus Sporormiella-type explains $26.5 \%$ of the vegetation data variance and are positively correlated with Castanea, Vitis, Plantago lanceolata, Alnus, Triticum-type and Poaceae pollen taxa.

Palynological richness has increased over time since the beginning of the Holocene (Figure 5). The expected number of pollen types has increased from 20 (c. 11,000 cal. BP) to 50 nowadays. This increase was more marked starting from c. $3500 \mathrm{cal}$. BP onwards, at the same time as the increase in cultivated species (Plantago, Olea europea, etc.) and Poaceae and the increase in Sporormiella-type (shift from Zone 5 to Zone 6). Pollen evenness showed the same increasing trend as palynological richness during all the Holocene. The increase was more marked before $7500 \mathrm{cal}$. BP, and then remained relatively constant until c. 3500 cal. BP, before a new increase, up to the present values. Palynological richness and pollen evenness showed positive correlation $($ rho $=0.72, p$ value $<0.001)$.

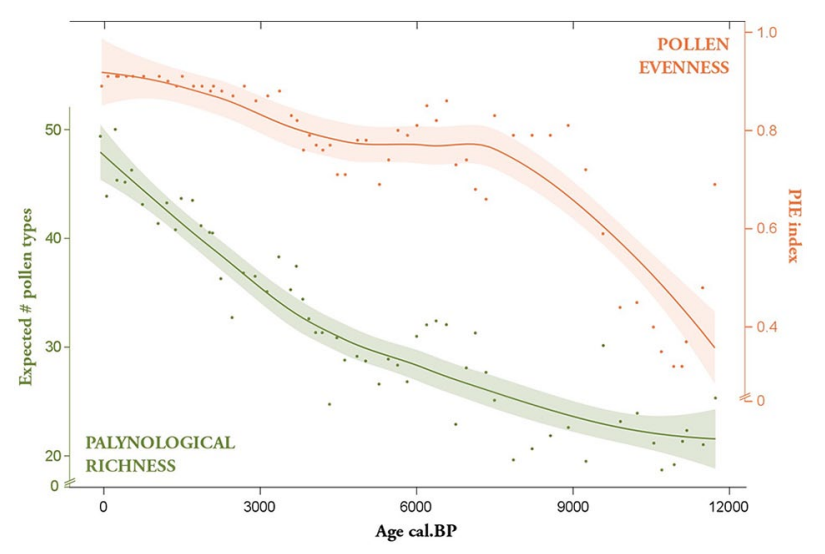

Figure 5. Comparison between palynological richness estimated on a constant sum of 693 pollen grains. Spearman's rank correlation between richness and evenness: rho $=0.73 / / p$ value $>0.00 \mathrm{I}$.

The palynological richness has been also plotted as a function of CHARnb and CHARar and Sporormiella-type influx to highlight potential correlations (Figure 6). We could not highlight a significant correlation between the palynological richness and CHAR, but we observed a maximum of richness for an intermediate value of CHAR around $0.5 \mathrm{\#} / \mathrm{cm}^{2} / \mathrm{yr}$ (number) and $1500 \mu \mathrm{m}^{2} / \mathrm{cm}^{2} / \mathrm{yr}$ (total area). Lower or higher CHAR values were related to lower richness. The Sporormiella-type influx ranged between 0 and $555 \# / \mathrm{cm}^{2} / \mathrm{yr}$ (mean was 96.81) and it was significantly positively correlated with palynological richness ( $r h o=0.74, p$ value $<0.01)$. The detailed results are available in the Supplementary materials (IV-VI), available online.

\section{Discussion}

\section{Dynamics of Corsican landscape during the Holocene}

The early Holocene was characterized by the recolonization of the woody vegetation (Reille, 1992b; Reille et al., 1999). At this time, our results, recording many CHAR peaks (Figure 3), suggest a sustained fire regime. The dry climatic conditions during the summer (Drescher-Schneider et al., 2007; Finsinger et al., 2010; Rossignol-Strick and Paterne, 1999; Vannière et al., 2011) adding to the increase in the fuel availability (Reille et al., 1999, 


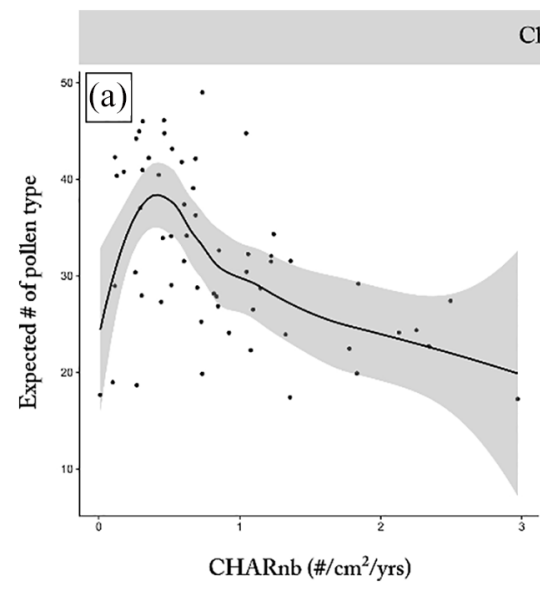

\section{Charcoals}

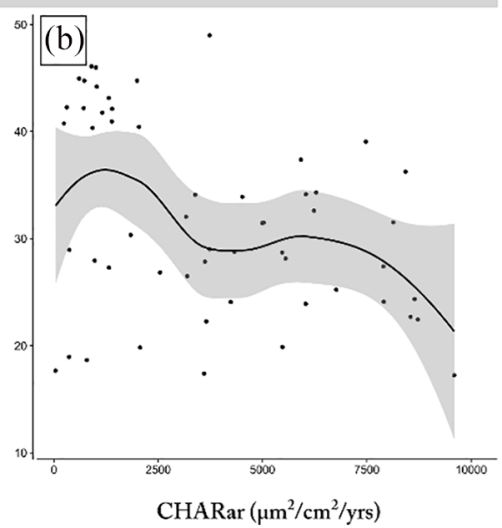

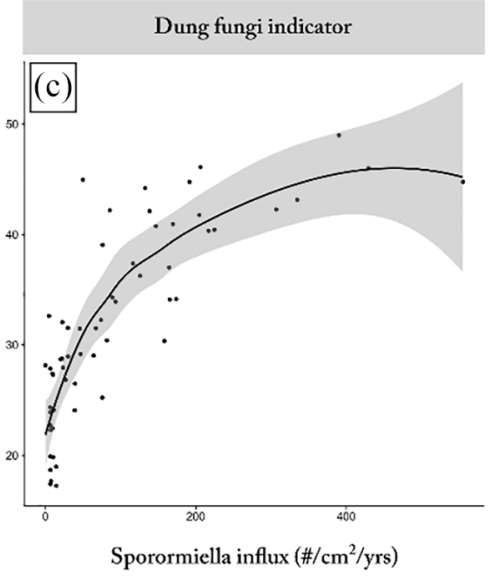

Figure 6. Palynological richness in function of (a) CHAR (number), (b) CHAR (area) and (c) Sporormiella influx.

1997) could have favoured fire ignition and propagation during the early Holocene. This trend has been observed in several Mediterranean sites (e.g. Vannière et al., 2008; Wick et al., 2003) including the Corsican Creno Lake (Leys et al., 2014). At this time, open to closed forest dominated by Pinus sp. explain a relatively low forest diversity and evenness, in particular for trees species (see Supplementary materials IV A, available online). A too strong increase in fire frequency or severity prevented the development of a diversified landscape, as suggested in our results (Figure 4) and supported by the literature (Aranbarri et al., 2014; Ladd et al., 2004).

Between 9500 and $7500 \mathrm{cal}$. BP, we observed a strong expansion of Erica, previously observed by Reille et al. (1999). Here, we assume that Erica pollen originate from Erica arborea considering that this species is the main type of Ericaceae growing in the hinterland of Corsica (Gamisans, 1999). Nowadays, Erica arborea is associated with other tree species such as Arbutus unedo or Pinus nigra (Leys et al., 2014; Reille et al., 1999). Moreover, these shrublands are generally considered as early successional communities (Beffa et al., 2016), and as fire-prone systems (Curt et al., 2011) well adapted thanks to high resprouting capacities (Lloret and López Soria, 1993; Lloret et al., 2004). These observations suggest that the vegetation was composed of a dense heather stratum. This period should correspond to a thermal optimum when Erica arborea may have reached higher elevation than pines. Models proposed by Pausas $(1999,2006)$ show that under a too high fire frequency, Pinus $s p$. decreases whereas Erica arborea increases, suggesting a change in structure from forest to shrublands with fire frequency increase. Moreover, the vital attribute model proposed by Noble and Slatyer (1980) emphasizes that one of the most important vital attributes correspond to the ability to establish and grow to maturity in the community. Because fires were more frequent at this time, pine probably did not have enough time to mature and produce seeds. From this point, and according to Beffa et al. (2016), we suggest that this mixed pine/heather forest corresponded to a transition state from a forest to a more open environment composed of heather. This dominance of Erica shrublands under high fire frequency was probably related to warmer/drier climate conditions than today.

A major event, already observed from sediments of Lake Creno (Reille et al., 1999), occurred around 7500 cal. BP, with the decrease of Pinus. For Reille et al. (1999), these changes are attributed to human activities. Moreover, during that period we are witnessing the increase in Poaceae, which supports the human impact hypothesis. Comparing our result with previous studies (Colombaroli et al., 2009; Leys et al., 2014; Reille et al., 1999), we suggest that the wetter climate characterized by low fire frequency and potential increase in the moisture availability
(Drescher-Schneider et al., 2007; Vannière et al., 2008), adding to decrease in fuel due to human activities (deforestation and pasture) (San Roman Sanz et al., 2013) also observed in Tuscany (Colombaroli et al., 2009; Finsinger et al., 2010), have favoured the evergreen Quercus establishment in Corsica. However, the relative part of both drivers (climate and human activities) is difficult to estimate and needs further study. The long fire-free period after this major event helped Quercus ilex-type and Quercus pubescens-type, which are late successional species, to colonize because they are better competitors than Pinus (pioneer species) in an undisturbed environment (Carcaillet et al., 1997; Colombaroli et al., 2009; Reille, 1992b). This marked expansion of Quercus was associated with a vegetation richness increase around $6500 \mathrm{cal}$. BP, as contemporaneously observed from Creno Lake (Reille et al., 1999) and regionally earlier observed (80009000 cal. BP) in central Italia (Colombaroli et al., 2007, 2008; Finsinger et al., 2010).

During the period that followed the development of these mixed oakwood forests, the analysis of pollen and dung fungal remains pinpointed the correlation between vegetation changes and human history. Sporormiella-type was recorded during the entire Bastani Lake sequence, probably corresponding to wild fauna, but a significant increase superimposed to the appearance of other dung fungal remains (e.g. Sordariales, Delitshia $s p$.) indicates the presence of large herbivores around the lake, at least since $5000 \mathrm{cal}$. BP. The frequentation of the lake area by livestock seems to be a plausible explanation for this dung fungal spore increase. Moreover, this hypothesis of human presence was followed by an increase in charcoal content, which could be explained by the land-use transformation from forest into crops and pastures through deforestation and use of fire (Janny and Costa, 2004). Indeed, the use of fire in European Neolithic cultures for land-use and clearance is widely attested (Carcaillet, 1998; Clark et al., 1989; Mouillot et al., 2008; Tinner et al., 2005; Vannière and Martineau, 2005; Vannière et al., 2008).

Such increase in biomass burning changed the tree composition by reducing oaks and promoting pines. This forest opening during the late-Holocene has also been observed in Sardinia (e.g. Beffa et al., 2016), Iberia (e.g. Pausas, 2004) and southern France, including Corsica from the palynological reconstruction from Creno Lake (e.g. Reille et al., 1999). Moreover, our results show a clear increase in anthropogenic activities indicators such as ruderal pollen types (e.g. Plantago-type) and a clear increase in pasture indicators such as Sporormiella-type suggesting that agricultural and pastoral activities were increasingly practised in the area. In agreement with other studies (e.g. Beffa et al., 2016; Colombaroli and Tinner, 2013; Vannière et al., 2008), and even though our results cannot totally rule out the role of climate, we mainly attribute this opening (increase in NAP and cultural 
indicators) to the increase in human activities (Ghilardi et al., 2017; Morelli and Francalacci, 2000).

After $1800 \mathrm{cal}$. BP, the decrease in charcoal-inferred fire signal combined with increase in the proportion of dung fungal spores and crop pollen suggest that human practices have changed and that the population better controlled fire. It is concomitant with the end of the Roman Empire, which induced a decrease in the human population at the island scale during the medieval period (Caratini, 1995; Morelli and Francalacci, 2000). Finally, since $800 \mathrm{cal}$. BP, human impact has been more and more visible, particularly by increase in dung fungal spores and by cultivated species (Triticum-type, Olea, Castanea). This increase could be explained by the strong Tuscan immigration into Corsica observed after 800 cal. BP (Morelli and Francalacci, 2000). These human activities, in particular crops and pasture, affected all ecosystems, from the Alpine belt with pastoralism to the Mediterranean sea level with olive groves. They have opened more and more the landscape up to the current Corsican landscape. This period of demographic increase (Morelli and Francalacci, 2000) contributed to increase in fire occurrences over the past centuries. Moreover, over the past few decades, decline in pastoral activities and land abandonment have been observed, causing a closure of the environment (Mouillot et al., 2005; San Roman Sanz et al., 2013). This closure combined with the global warming (in particular the increase in summer temperature) could promote future uncontrolled fires (Giannakopoulos et al., 2005; Moriondo et al., 2006; Mouillot et al., 2002, 2003).

\section{Fuel and fire-type changes: from pinewood crown fire to slash-and-burn practices}

This study participates in the charcoal classification using the W/L ratio and a new method to compare the regularity of charcoal particle contours by calculating the $\mathrm{A} / \mathrm{P}$ ratio. These methods have the great advantage of being independent of each other. As it is an automated measure, these index accuracies are not related to the observer and are reusable for any other samples. Finally, the use of both CHARnb and CHARar to estimate the change in the particle size is a king of sensitivity analysis that reinforces our findings.

Our results highlighted that each of the three main fire-prone periods was associated with different charcoal morphologies. During the first period $(11,500-6500 \mathrm{cal}$. BP), the mean particle size was small, geometric and not much elongated but particles were numerous, which corresponds to what we described as the homogeneous pinewood period characterized by frequent fire episodes. As explained previously, the shape of our charcoals could be explained in many ways: first, charcoals could have undergone much reshuffle (e.g. Ali et al., 2009; Vannière et al., 2003), second, the signal captured may come from a long distance (e.g. Clark and Royall, 1995) and finally, the fuel was more woody than herbaceous (e.g. Umbanhowar and Mcgrath, 1998). Because this period of intense biomass burning at the early Holocene has been observed in every Corsican well-dated study (e.g. Carcaillet et al., 1997; Leys et al., 2014), we can logically say that this signal corresponds to a global trend for Corsica. Moreover, pinewoods in the Mediterranean basin tend to engender crown fires (Pausas et al., 2009), so the typical shape of our charcoals can also reflect a majority of woody fuels.

The second period (5000-1800 cal. BP) was characterized by large, elongated and indented particles. We described this period as driven by human activities like slash-and-burn practices. According to previous studies (Enache and Cumming, 2007; Jensen et al., 2007; Mustaphi and Pisaric, 2014; Umbanhowar and Mcgrath, 1998), and to other Corsican studies (Carcaillet et al., 1997; Leys, 2012; Leys et al., 2014; Reille, 1992b; Reille et al., 1999), our results could reflect a more herbaceous fuel and local signal induced by the development of human activities (e.g. maintenance of open landscapes). Because increased charcoal influx may be associated with higher fuel consumption (one aspect of fire severity) (Dunnette et al., 2014; Feurdean et al., 2017; Higuera et al., 2011), the higher charcoal peak magnitude at this period could also indicate higher fire severity and/or larger burned area (Duffin et al., 2008; Feurdean et al., 2017; Higuera et al., 2009).

During the third period covering the last centuries, the pollen grains have been smaller than ever and the charcoals particles have been more geometric and less elongated. We described this period by an opening of the landscape and an increase in the fire signal, mainly due to human activities. This observation reflects a global trend, for Corsica (Leys et al., 2014) and worldwide (Blarquez et al., 2015; Syphard et al., 2007; Li et al., 2017; Vannière et al., 2016). This shift at 800 cal. BP with small and compact charcoals was also highlighted in Italy (lago dell'Accesa; Vannière et al., 2008). The authors associated that as a result of erosional processes highlighted by changes in the accumulation rate since 1800 years, which are linked with agricultural activities that implemented other uses of fire than before (Bajard et al., 2017; Giguet-Covex et al., 2014). Our pollen and fungal remains results suggest that most parts of the area were open and used as crop fields or pastures. Based on the Bastani Lake watershed particularities (small size, no-steep slope and high elevation), erosion was likely very limited and observed terrigenous inputs were more probably due to African dusts. We have not enough results to discuss dust contribution to sedimentation in detail in this study, but a more complete study on Bastani erosion will soon be available (P Sabatier, personal communication). From these observations, it seems that human activities could have contributed to increase fire frequencies, and the changes in charcoal morphotypes probably correspond to a change in the kind of fire and fuel.

\section{Did fire and human activities control or affect biodiversity?}

The representativeness of the vegetation diversity by pollen is controversial (Goring et al., 2013; Odgaard, 2006). However, it is actually the only way to have an idea of the past vegetation diversity. Moreover, in their review, Birks et al. (2016) show that pollen richness is a good indicator of vegetation richness. So, while a valuable measure of long-term biodiversity changes (e.g. Colombaroli and Tinner, 2013), these results must be interpreted carefully (Felde et al., 2016; Meltsov et al., 2011; Odgaard, 2001; Weng et al., 2006). Because palynological richness and pollen evenness are largely positively correlated, we assume that pollen evenness has an effect on palynological richness (Beffa et al., 2016; Colombaroli and Tinner, 2013).

In their review, Pausas and Ribeiro (2017) highlight that fire can drive plant diversity in various ways. Fire regime can drive population divergence and diversification (Bytebier et al., 2011; Pausas, 2015) and it can generate landscape mosaics and thus more habitat types and more niches likely to be filled by different species (Bird et al., 2008; Bond and Keeley, 2005; Cohn et al., 2015; Leys et al., 2018). In this sense, fire would increase vegetation evenness by generating the biotic heterogeneity that drives diversity (Stein et al., 2014). This positive impact of fire on vegetation is observed when both the CHAR and the palynological richness increased simultaneously (Figure 6). Nevertheless, beyond a certain value (i.e. visually around $0.5 \# / \mathrm{cm}^{2} / \mathrm{yr}$.), fire frequency induced a strong decrease in the palynological richness. Such observation is in line with the intermediate-disturbance hypothesis (Fox, 1979), suggesting that when the disturbance (here fire) is almost absent (here low CHAR), the interspecific competition increases and several species disappear. Conversely, 
when the disturbance is too strong (here high CHAR), species are not adapted anymore and the post-fire recovery only allows a few species (the most adapted). Similar trends for the long-term millennial scale have been observed by Colombaroli and Tinner (2013).

Previously, we discussed the role of humans in setting up the current Corsican vegetation. In addition, our results highlight that the increase in pasture (detected by dung fungi indicator) promoted high plant diversity (Figure 6). These results agree with another recent study from the Mediterranean region (Portugal; Listopad et al., 2018). They showed that a grazing exclusion shorter than 5 years promotes a high diversity of herbs and shrubs, whereas a longer period will promote a higher diversity and height of trees, which in turn, will allow them to be protected from further grazing (i.e. bush encroachment effect). Currently, the high Corsican plant diversity is mainly composed of shrubs and herbs forming a landscape of maquis (e.g. Mouillot et al., 2005; Saitta et al., 2018). According to our observations and other studies (Correia, 1993; Saïd, 2002; Sedlar et al., 2018), and even though our results did not permit to totally exclude the climate as a significant driver, we suggest that this currently high diversified Corsican landscape is mainly due to millennia of traditional management practices, in particular pasture. However, the abandonment of these traditional human activities observed since a few decades (Mouillot et al., 2005), adding to the increase in invasive species due to international exchanges (Traveset et al., 2008), could probably (1) promote future forest rather than maquis expansion, (2) induce a loss of biodiversity (Médail and Verlaque, 1997; Saï, 2002) and (3) increase the fuel availability. Combined with the dryer climate predicted for the next decades due to global warming (Giannakopoulos et al., 2009; Sheffield and Wood, 2008), we can expect a strong increase in fire frequency and intensity for the next decades, similar to those from the early Holocene, despite the fire suppression efforts (Lahaye et al., 2014). This fire-prone climate adding to the fuel increase threatens the important Corsican plant diversity.

\section{Conclusion}

A high-resolution analysis of charcoal, pollen and fungal remains in lacustrine sediments from the Lake Bastani permitted to reconstruct precisely fire history, land cover changes and land-use dynamics of a representative region of Corsica and the Mediterranean basin. Since 11,000 cal. BP, vegetation has been dense and dominated by Pinus with a low diversity, in particular for tree species. The dry summer conditions have induced intensive and frequent fires. The numerous occurrences of fire during the millennia contributed to opening the environment with the development of Erica heather until $7500 \mathrm{cal}$. BP. Then, the decrease in fire events induced a closure of the forest by the colonization of mixed oak forests. From 5000 cal. BP, humans seem to have been the main driver of vegetation dynamics and fire occurrences by deforesting and developing crops, and pastures, using fire. These changes are supported by changes in the charcoal morphotypes, and agree with many Mediterranean studies, attesting again the potential of the Bastani Lake to reflect global changes for the Mediterranean region. Thereby, it is placed in the lineage of other high-elevation Corsican lakes (e.g. Lake Creno, Reille et al., 1999), which reflect at least the whole island history. Moreover, we have observed many similarities with other Mediterranean sites (e.g. the early Holocene characterized by many fires, first human impacts on fires around $7500 \mathrm{cal}$. BP that promoted the expansion of Quercus ilex...), in particular in Sardinia (Beffa et al., 2016; Morelli and Francalacci, 2000) and Tuscany (Colombaroli et al., 2008; Finsinger et al., 2010; Vannière et al., 2008). This illustrates a global trend that probably occurred on the entire northern part of the Mediterranean basin.
Based on the present palaeoecological record, we suggest that climate and natural fires were the main factors shaping the landscape before $5000 \mathrm{cal}$. BP. However, the extraordinary diversity of herbs, shrubs and trees in the current Corsican landscape is mainly due to human practices, in particular since the Bronze Age (3500 cal. BP), as they promoted ecosystem diversity and niche availability (e.g. Colombaroli et al., 2008; Connor et al., 2019). We currently assist to a decrease in pastoral activities and the land abandonment associated with it (Correia, 1993; Mouillot et al., 2005; San Roman Sanz et al., 2013), which increases fuel availability. Moreover, the increase in human density could increase the fire hazard (Lahaye et al., 2018, 2014). Adding to the global warming and the dryer climate associated to it, the next decades should be characterized by an increase in fire frequency and intensity. These changes could affect the plant diversity of Corsica, such as predicted for European forests, from the temperate to the southern Mediterranean region (Pausas and Ribeiro, 2017; Pausas et al., 2009; Rundel et al., 2013).

One next step would be to model these past fire regimes and past vegetation in order to gain control of the underlying mechanisms. For this reason, we have to work on ecosystem management based on vegetation and fire relationships. To do so, we urgently need to continue investigation on the vegetation biodiversity dynamics associated with the fire and human activity dynamics in this region, in order to avoid human and economic damages and irrecoverable biodiversity losses within the near future.

\section{Acknowledgements}

This study is part of the PAGES-GPWG activities. The authors thank the Environnemental Office of Corsica, the town of Ghisoni and the National Forest Office for the lake access permit. They also thank Walter Finsinger for his help during coring fieldwork.

\section{Funding}

The author(s) disclosed receipt of the following financial support for the research, authorship and/or publication of this article: This study was founded by Région Bourgogne Franche-Comté through the Chrono-environnement laboratory, the MSHE Ledoux and the projects ONOMAD, QMedFire and ENVILEG led by BV. This study was also supported by the CNRS PaléoMEx-MISTRALS programme.

\section{ORCID iD}

Marion Lestienne (iD https://orcid.org/0000-0002-7229-2300

\section{Supplemental material}

Supplemental material for this article is available online.

\section{References}

Ali AA, Higuera PE, Bergeron Y et al. (2009) Comparing firehistory interpretations based on area, number and estimated volume of macroscopic charcoal in lake sediments. Quaternary Research 72(3): 462-468.

Aranbarri J, González-Sampériz P, Valero-Garcés B et al. (2014) Rapid climatic changes and resilient vegetation during the Lateglacial and Holocene in a continental region of southwestern Europe. Global and Planetary Change 114: 50-65.

Bajard M, Poulenard J, Sabatier P et al. (2017) Long-term changes in alpine pedogenetic processes: Effect of millennial agro-pastoralism activities (French-Italian Alps). Geoderma 306: 217-236.

Baker A, Bhagwat S and Willis K (2013) Do dung fungal spores make a good proxy for past distribution of herbivores? Quaternary Science Reviews 62: 21-31.

Beffa G, Pedrotta T, Colombaroli D et al. (2016) Vegetation and fire history of coastal north-eastern Sardinia (Italy) under 
changing Holocene climates and land use. Vegetation History and Archaeobotany 25(3): 271-289.

Bird RB, Bird DW, Codding BF et al. (2008) The 'fire stick farming' hypothesis: Australian aboriginal foraging strategies, biodiversity, and anthropogenic fire mosaics. Proceedings of the National Academy of Sciences 105(39): 14796-14801.

Birks HJB and Line JM (1992) The use of rarefaction analysis for estimating palynological richness from quaternary pollenanalytical data. The Holocene 2(1): 1-10.

Birks HJB, Felde VA, Bjune AE et al. (2016) Does pollen-assemblage richness reflect floristic richness? A review of recent developments and future challenges. Review of Palaeobotany and Palynology 228: 1-25.

Blaauw M (2010) R-Code for 'classical' age-modelling (CLAM V1.0) of radiocarbon sequences. Supplement to: Blaauw, M (2010): Methods and code for 'classical' age-modelling of radiocarbon sequences. Quaternary Geochronology, 5(5), 512518, https://doi.org/10.1016/j.quageo. Available at: https:// doi.pangaea.de/10.1594/PANGAEA.873023: doi:https://doi. org/10.1594/PANGAEA.873023

Blarquez O, Ali AA, Girardin MP et al. (2015) Regional paleofire regimes affected by non-uniform climate, vegetation and human drivers. Scientific Reports 5(1): 13356. Available at: http://www.nature.com/articles/srep13356: doi:10.1038/ srep13356

Bond WJ and Keeley JE (2005) Fire as a global 'herbivore': The ecology and evolution of flammable ecosystems. Trends in Ecology \& Evolution 20(7): 387-394.

BRGM (2009) Carte Géologique Harmonisée Du Département De La Haute-corse. Available at: http://infoterre.brgm.fr /rapports/RP-57748-FR.pdf

Bytebier B, Antonelli A, Bellstedt DU et al. (2011) Estimating the age of fire in the Cape flora of South Africa from an orchid phylogeny. Proceedings of the Royal Society of London B: Biological Sciences 278(1703): 188-195.

Caratini R (1995) Histoire Du Peuple Corse. New York: Criterion.

Carcaillet C (1998) A spatially precise study of Holocene fire history, climate and human impact within the Maurienne valley, North French Alps. Journal of Ecology 86(3): 384-396.

Carcaillet C, Barakat HN, Panaïotis C et al. (1997) Fire and lateHolocene expansion of Quercus ilex and Pinus pinaster on Corsica. Journal of Vegetation Science 8(1): 85-94.

Carcaillet C, Bouvier M, Fréchette B et al. (2001) Comparison of pollen-slide and sieving methods in lacustrine charcoal analyses for local and regional fire history. The Holocene 11(4): 467-476.

Carcaillet C, Perroux A-S, Genries A et al. (2007) Sedimentary charcoal pattern in a karstic underground lake, Vercors massif, French Alps: Implications for palaeo-fire history. The Holocene 17(6): 845-850.

Clark JS and Royall PD (1995) Particle-size evidence for source areas of charcoal accumulation in Late-Holocene sediments of eastern North American lakes. Quaternary Research 43(1): $80-89$.

Clark JS, Merkt J and Muller H (1989) Post-glacial fire, vegetation, and human history on the northern alpine forelands, south-western Germany. The Journal of Ecology 77: 897-925.

Cohn JS, Di Stefano J, Christie F et al. (2015) How do heterogeneity in vegetation types and post-fire age-classes contribute to plant diversity at the landscape scale? Forest Ecology and Management 346: 22-30.

Colombaroli D and Tinner W (2013) Determining the long-term changes in biodiversity and provisioning services along a transect from Central Europe to the Mediterranean. The Holocene 23(11): 1625-1634.
Colombaroli D, Marchetto A and Tinner W (2007) Long-term interactions between Mediterranean climate, vegetation and fire regime at Lago di Massaciuccoli (Tuscany, Italy). Journal of Ecology 95(4): 755-770.

Colombaroli D, Tinner W, Leeuwen JV et al. (2009) Response of broadleaved evergreen Mediterranean forest vegetation to fire disturbance during the Holocene: Insights from the periAdriatic region. Journal of Biogeography 36(2): 314-326.

Colombaroli D, Vannière B, Emmanuel C et al. (2008) Fire - vegetation interactions during the Mesolithic - Neolithic transition at Lago dell' Accesa, Tuscany, Italy. The Holocene 18(5): 679-692.

Conchon O (1988) Manifestation et chronologie de la déglaciation fini-würmiennne en Corse. Bulletin De L'association Française Pour L'étude Du Quaternaire 25(2): 91-96.

Correia T (1993) Land abandonment: Changes in the land use patterns around the Mediterranean basin. Cahiers Options Méditerranéennes 1(2): 97-112.

Cowling RM, Rundel PW, Lamont BB et al. (1996) Plant diversity in Mediterranean-climate regions. Trends in Ecology \& Evolution 11(9): 362-366.

Cugny C, Mazier F and Galop D (2010) Modern and fossil nonpollen palynomorphs from the Basque mountains (western Pyrenees, France): The use of coprophilous fungi to reconstruct pastoral activity. Vegetation History and Archaeobotany 19: 391-408. doi:10.1007/s00334-010-0242-6

Curt T, Schaffhauser A, Borgniet L et al. (2011) Litter flammability in oak woodlands and shrublands of southeastern France. Forest Ecology and Management 261(12): 2214-2222.

Dixon P (2003) VEGAN, a package of R functions for community ecology. Journal of Vegetation Science 14(6): 927-930.

Drescher-Schneider R, De Beaulieu J-L, Magny M et al. (2007) Vegetation history, climate and human impact over the last 15,000 years at Lago dell'Accesa (Tuscany, Central Italy). Vegetation History and Archaeobotany 16(4): 279-299.

Duffin KI, Gillson L and Willis KJ (2008) Testing the sensitivity of charcoal as an indicator of fire events in savanna environments: Quantitative predictions of fire proximity, area and intensity. The Holocene 18(2): 279-291.

Dunnette PV, Higuera PE, McLauchlan KK et al. (2014) Biogeochemical impacts of wildfires over four millennia in a Rocky Mountain subalpine watershed. New Phytologist 203(3): 900-912.

Ellis MB and Ellis JP (1985) Microfungi on Land Plants. An Identification Handbook. London: Croom Helm Ltd.

Enache MD and Cumming BF (2006) Tracking recorded fires using charcoal morphology from the sedimentary sequence of Prosser Lake, British Columbia (Canada). Quaternary Research 65(2): 282-292.

Enache MD and Cumming BF (2007) Charcoal morphotypes in lake sediments from British Columbia (Canada): An assessment of their utility for the reconstruction of past fire and precipitation. Journal of Paleolimnology 38(3): 347-363.

Etienne D and Jouffroy-Bapicot I (2014) Optimal counting limit for fungal spore abundance estimation using Sporormiella as a case study. Vegetation History and Archaeobotany 23(6): 743-749.

Fægri K and Iversen J (1989) A Textbook of Pollen Analysis. Journal of Biogeography 2: 310.

Felde VA, Peglar SM, Bjune AE et al. (2016) Modern pollen-plant richness and diversity relationships exist along a vegetational gradient in southern Norway. The Holocene 26(2): 163-175.

Feurdean A, Florescu G, Vannière B et al. (2017) Fire has been an important driver of forest dynamics in the Carpathian Mountains during the Holocene. Forest Ecology and Management 389: $15-26$. 
Finsinger W, Colombaroli D, De Beaulieu J-L et al. (2010) Early to mid-Holocene climate change at Lago dell'Accesa (central Italy): Climate signal or anthropogenic bias? Journal of Quaternary Science 25(8): 1239-1247.

Fox JF (1979) Intermediate-disturbance hypothesis. Science 204(4399): 1344-1345.

Gamisans J (1999) La Végétation De La Corse. Aix-en-Provence: Edisud.

Gauthier A, Frisoni G-F and Roché B (1984) Contribution a la connaissance des lacs d'altitude de la Corse: rapport éd. en mai 1984 par le CRCP pour le Parc Naturel Regional de la Corse. Corte: Parc Naturel Regional de la Corse.

Gauthier A, Roche B and Frisoni G-F (1983) Contribution à la connaissance des lacs d'altitudes de Corse. Corte: Parc Naturel Regional de la Corse.

Ghilardi M, Istria D, Curras A et al. (2017) Reconstructing the landscape evolution and the human occupation of the Lower Sagone River (Western Corsica, France) from the Bronze Age to the Medieval period. Journal of Archaeological Science: Reports 12: 741-754.

Giannakopoulos C, Bindi M, Moriondo M et al. (2005) Climate Change Impacts in the Mediterranean Resulting from a $2 \mathrm{C}$ Global Temperature Rise: A report for WWF. Available at: http://mediterranean.panda.org/publications/?21632/Climatechange-impacts-in-the-Mediterranean-resulting-from-a-2 -degrees-C-global-temperature-rise (accessed 4 October 2019).

Giannakopoulos C, Le Sager P, Bindi M et al. (2009) Climatic changes and associated impacts in the Mediterranean resulting from a $2 \mathrm{C}$ global warming. Global and Planetary Change 68(3): 209-224.

Giguet-Covex C, Pansu J, Arnaud F et al. (2014) Long livestock farming history and human landscape shaping revealed by lake sediment DNA. Nature Communications 5: 3211.

Giorgi F (2006) Climate change hot-spots. Geophysical Research Letters 33(8): 101029.

Giorgi F and Lionello P (2008) Climate change projections for the Mediterranean region. Global and Planetary Change 63(2): 90-104.

Goring S, Lacourse T, Pellatt Marlow G et al. (2013) Pollen assemblage richness does not reflect regional plant species richness: A cautionary tale. Journal of Ecology 101(5): 1137-1145.

Grimm EC (1991) Tilia and tiliagraph. Springfield, IL: Illinois State Museum.

Grimm EC (2004) TILIA and TGView software, version 2.0.2. Illinois State University, Springfield.

Higuera P (2009) CharAnalysis 0.9: Diagnostic and analytical tools for sedimentcharcoal analysis: User's Guide. Bozeman, MT: Montana State University.

Higuera PE, Brubaker LB, Anderson PM et al. (2009) Vegetation mediated the impacts of postglacial climate change on fire regimes in the south-central Brooks Range, Alaska. Ecological Monographs 79(2): 201-219.

Higuera PE, Gavin DG, Bartlein PJ et al. (2011) Peak detection in sediment-charcoal records: Impacts of alternative data analysis methods on fire-history interpretations. International Journal of Wildland Fire 19(8): 996-1014.

Hurlbert S (1971) The Nonconcept of Species Diversity: A Critique and Alternative Parameters. Ecology 52(4): 577-586.

Janny F and Costa LJ (2004) Évolution et transformation des industries lithiques taillées et polies durant le Chalcolithique et l'Âge du Bronze en Corse. L'anthropologie 108(1): $111-119$.

Jensen K, Lynch EA, Calcote R et al. (2007) Interpretation of charcoal morphotypes in sediments from Ferry Lake, Wisconsin, USA: Do different plant fuel sources produce distinctive charcoal morphotypes? The Holocene 17(7): 907-915.

Keeley JE (2009) Fire intensity, fire severity and burn severity: A brief review and suggested usage. International Journal of Wildland Fire 18(1): 116.
Ladd PG, Crosti R and Pignatti S (2004) Vegetative and seedling regeneration after fire in planted Sardinian pinewood compared with that in other areas of Mediterranean-type climate. Journal of Biogeography 32(1): 85-98.

Lahaye S, Curt T, Fréjaville T et al. (2018) What are the drivers of dangerous fires in Mediterranean France? International Journal of Wildland Fire 27(3): 155-163.

Lahaye S, Curt T, Paradis L et al. (2014) Classification of Large Wildfires in South-eastern France to Adapt Suppression Strategies. Imprensa da Universidade de Coimbra. Available at: https://hal.archives-ouvertes.fr/hal-01128654/

Lepš J and Šmilauer P (2003) Multivariate Analysis of Ecological Data Using CANOCO. Cambridge: Cambridge University Press.

Lestienne MC, Aleman J and Colombaroli D (2017) How Paleofire Research Can Better Inform Ecosystem Management. Earth \& Space Science News (EOS) 99(8): 12.

Leys B (2012) Facteurs explicatifs de la dynamique des végétations au cours de l'Holocène en système montagnard méditerranéen et alpin: Climat et perturbation feu. EPHE. Available at: https://www.researchgate.net/publication/235915397 _Facteurs_explicatifs_de_la_dynamique_des_vegetations _au_cours_de_1\%27Holocene_en_systeme_montagnard _mediterraneen_et_alpin_climat_et_perturbation_feu

Leys B, Carcaillet $\bar{C}, \bar{D}$, charcoal measurements for reconstruction of Mediterranean paleo-fire frequency in the mountains of Corsica. Quaternary Research 79(3): 337-349.

Leys B, Curt T and Elkin C (2018) Mosaic landscape pattern explains vegetation resistance to high fire frequency in Corsica over the last six millennia. Int J Earth Sci Geophys 4: 017.

Leys B, Finsinger W and Carcaillet C (2014) Historical range of fire frequency is not the Achilles' heel of the Corsican black pine ecosystem. Journal of Ecology 102(2): 381-395.

Leys BA, Commerford JL and McLauchlan KK (2017) Reconstructing grassland fire history using sedimentary charcoal: Considering count, size and shape. PLoS ONE 12(4): e0176445.

Li Y, Zhao J, Guo X et al. (2017) The influence of land use on the grassland fire occurrence in the Northeastern Inner Mongolia autonomous region, China. Sensors 17(3): 437.

Listopad CMCS, Köbel M, Príncipe A et al. (2018) The effect of grazing exclusion over time on structure, biodiversity, and regeneration of high nature value farmland ecosystems in Europe. Science of the Total Environment 610-611: 926-936.

Lloret F and López Soria L (1993) Resprouting of Erica multiflora after experimental fire treatments. Journal of Vegetation Science 4(3): 367-374.

Lloret F, Siscart D and Dalmases C (2004) Canopy recovery after drought dieback in holm-oak Mediterranean forests of Catalonia (NE Spain). Global Change Biology 10(12): 2092-2099.

Médail F (2017) The specific vulnerability of plant biodiversity and vegetation on Mediterranean islands in the face of global change. Regional Environmental Change 17(6): 1775-1790.

Medail F and Quezel P (1997) Hot-spots analysis for conservation of plant biodiversity in the Mediterranean Basin. Annals of the Missouri Botanical Garden 84: 112-127.

Médail F and Verlaque R (1997) Ecological characteristics and rarity of endemic plants from southeast France and Corsica: Implications for biodiversity conservation. Biological Conservation 80(3): 269-281.

Meltsov V, Poska A, Odgaard BV et al. (2011) Palynological richness and pollen sample evenness in relation to local floristic diversity in southern Estonia. Review of Palaeobotany and Palynology 166(3-4): 344-351.

Morelli L and Francalacci P (2000) The population history of Corsica and Sardinia: The contribution of archaeology and genetics. In: Renfrew C and Boyler K (eds) Archaeogenetics: 
DNA and the Population Prehistory of Europe. Cambridge: McDonald Institute for Archaeological Research, p. 185.

Moriondo M, Good P, Durao R et al. (2006) Potential impact of climate change on fire risk in the Mediterranean area. Climate Research 31(1): 85-95.

Mouillot F, Paradis G, Andrei-Ruiz M-C et al. (2008) Corsica. In: Vogiatzakis IN, Pungetti G and Mannion AM (eds) Mediterranean Island Landscapes: Natural and Cultural Approaches. New York: Springer, pp. 220-244.

Mouillot F, Rambal S and Joffre R (2002) Simulating climate change impacts on fire frequency and vegetation dynamics in a Mediterranean-type ecosystem. Global Change Biology 8(5): 423-437.

Mouillot F, Ratte J-P, Joffre R et al. (2003) Some determinants of the spatio-temporal fire cycle in a Mediterranean landscape (Corsica, France). Landscape Ecology 18(7): 665-674.

Mouillot F, Ratte J-P, Joffre R et al. (2005) Long-term forest dynamic after land abandonment in a fire prone Mediterranean landscape (central Corsica, France). Landscape Ecology 20(1): 101-112.

Mustaphi CJC and Pisaric MFJ (2014) A classification for macroscopic charcoal morphologies found in Holocene lacustrine sediments. Progress in Physical Geography 38(6): 734-754.

Noble IR and Slatyer RO (1980) The use of vital attributes to predict successional changes in plant communities subject to recurrent disturbances. Vegetatio 43(1-2): 5-21.

Odgaard BV (2001) Fossil pollen as a record of past biodiversity. Journal of Biogeography 26(1): 7-17.

Odgaard BV (2006) Biodiversity of past plant cover. In: Elias SA (ed.) Encyclopedia of Quaternary Science. Oxford: Pergamon Press, pp. 2511-2515.

Patterson WA, Edwards KJ and Maguire DJ (1987) Microscopic charcoal as a fossil indicator of fire. Quaternary Science Reviews 6(1): 3-23.

Pausas JG (1999) Response of plant functional types to changes in the fire regime in Mediterranean ecosystems: A simulation approach. Journal of Vegetation Science 10(5): 717-722.

Pausas JG (2004) Changes in fire and climate in the eastern Iberian Peninsula (Mediterranean basin). Climatic Change 63(3): $337-350$

Pausas JG (2006) Simulating Mediterranean landscape pattern and vegetation dynamics under different fire regimes. Plant Ecology 187(2): 249-259.

Pausas JG (2015) Bark thickness and fire regime. Functional Ecology 29(3): 315-327.

Pausas JG and Fernández-Muñoz S (2012) Fire regime changes in the Western Mediterranean Basin: From fuel-limited to drought-driven fire regime. Climatic Change 110(1-2): $215-226$

Pausas JG and Ribeiro E (2017) Fire and plant diversity at the global scale. Global Ecology and Biogeography 26(8): 889-897.

Pausas JG, Llovet J, Rodrigo A et al. (2009) Are wildfires a disaster in the Mediterranean basin? - A review. International Journal of Wildland Fire 17(6): 713-723.

Piñol J, Terradas J and Lloret F (1998) Climate warming, wildfire hazard, and wildfire occurrence in Coastal Eastern Spain. Climatic Change 38(3): 345-357.

Quezel P (1999) Les grandes structures de végétation en région méditerranéenne: Facteurs déterminants dans leur mise en place post-glaciaire. Geobios 32(1): 19-32.

Reille M (1992a) Pollen et Spores D'Europe et D'Afrique du Nord. Marseille: Laboratoire De Botanique Historique Et Palynologie.

Reille M (1992b) New pollen-analytical researches in Corsica: The problem of Quercus ilex L. and Erica arborea L., the origin of Pinus halepensis Miller forests. New Phytologist 122(2): 359-378.

Reille M, Gamisans J, Andrieu-Ponel V et al. (1999) The Holocene at Lac de Creno, Corsica, France: A key site for the whole island. The New Phytologist 141(2): 291-307.

Reille M, Gamisans J, de Beaulieu JL et al. (1997) The late-glacial at Lac de Creno (Corsica, France): A key site in the western Mediterranean basin. New Phytologist 135(3): 547-559.

Rhodes AN (1998) A method for the preparation and quantification of microscopic charcoal from terrestrial and lacustrine sediment cores. Holocene 8: 113-117.

Roche B and Loye-Pilot MD (1989) Eutrophisation récente d'un lac de montagne sans occupation humaine (lac de Bastani, Corset: Conséquence d'agents atmosphériques? Revue Des Sciences De L'eau / Journal of Water Science 2(4): 681-707.

Rossignol-Strick M and Paterne M (1999) (Table 1) Comparison of three chronologies for the sapropel series of cores KC01KC01b. Supplement to: Rossignol-Strick, M; Paterne, M 1999: A synthetic pollen record of the eastern Mediterranean sapropels of the last $1 \mathrm{Ma}$ : Implications for the time-scale and formation of sapropels. Marine Geology, 1531(4), 221-237, https://doi.org/10.1016/S0025-32279800080-2. Available at: https://doi.pangaea.de/10.1594/PANGAEA.790758

Rundel PW, Montenegro G and Jaksic FM (2013) Landscape Disturbance and Biodiversity in Mediterranean-type Ecosystems. New York: Springer.

Sá ACL, Benali A, Fernandes PM et al. (2017) Evaluating fire growth simulations using satellite active fire data. Remote Sensing of Environment 190: 302-317.

Saïd S (2002) Floristic and life form diversity in post-pasture successions on a Mediterranean island (Corsica). Plant Ecology 162(1): 67-76.

Saitta A, Anslan S, Bahram M et al. (2018) Tree species identity and diversity drive fungal richness and community composition along an elevational gradient in a Mediterranean ecosystem. Mycorrhiza 28(1): 39-47.

San Roman Sanz A, Fernandez C, Mouillot F et al. (2013) Longterm forest dynamics and land-use abandonment in the Mediterranean mountains, Corsica, France. Ecology and Society 18(2): 38. Available at: https://www.ecologyandsociety.org/ vol18/iss2/art38/: doi:10.5751/ES-05556-180238

Sedlar Z, Alegro A, Radović A et al. (2018) Extreme land-cover and biodiversity change as an outcome of land abandonment on a Mediterranean island (eastern Adriatic). Plant Biosystems 152(4): 728-737.

Sheffield J and Wood EF (2008) Projected changes in drought occurrence under future global warming from multi-model, multi-scenario, IPCC AR4 simulations. Climate Dynamics 31(1): 79-105.

Spearman C (1904) The proof and measurement of association between two things. The American Journal of Psychology 15(1): 72-101.

Stein A, Gerstner K and Kreft H (2014) Environmental heterogeneity as a universal driver of species richness across taxa, biomes and spatial scales. Ecology Letters 17(7): 866-880.

Syphard AC, Volker RE, Keeley JJ et al. (2007) Human influence on California fire regimes. Ecological Applications 17(5): $1388-1402$.

Stockmarr JA (1971) Tablets with spores used in absolute pollen analysis. Pollen Spores 13: 615-621.

Ter Braak CJ and Smilauer P (2002) CANOCO Reference Manual and Canodraw for Windows User's Guide: Software for Canonical Community Ordination (Version 4.5). Available at: www.canoco.com 
Tinner W, Conedera M, Ammann B et al. (2005) Fire ecology north and south of the Alps since the last ice age. The Holocene 15(8): 1214-1226.

Traveset A, Brundu G, Carta L et al. (2008) Consistent performance of invasive plant species within and among islands of the Mediterranean basin. Biological Invasions 10(6): 847-858.

Umbanhowar CE and Mcgrath MJ (1998) Experimental production and analysis of microscopic charcoal from wood, leaves and grasses. The Holocene 8(3): 341-346.

Van Geel B (2002) Non-pollen palynomorphs. In: Smol JP, Birks HJ and Last WM (eds) Tracking environmental change using lake sediments. Dordrecht: Springer, pp. 99-119.

Van Geel B and Aptroot A (2006) Fossil ascomycetes in Quaternary deposits. Nova Hedwigia 82(3-4): 313-329.

Vannière B and Martineau R (2005) Histoire des feux et pratiques agraires du Néolithiqueàl'âge du Fer en région Centre: Implications territoriales, démographiques et environnementales. Gallia Préhistoire 47(1): 167-186.

Vannière B, Blarquez O, Rius D et al. (2016) 7000-year human legacy of elevation-dependent European fire regimes. Quaternary Science Reviews 132: 206-212.

Vannière B, Bossuet G, Walter-Simonnet AV et al. (2003) Land use change, soil erosion and alluvial dynamic in the lower Doubs Valley over the 1st millennium AD (Neublans, Jura, France). Journal of Archaeological Science 30(10): 1283-1299.
Vannière B, Colombaroli D, Chapron E et al. (2008) Climate versus human-driven fire regimes in Mediterranean landscapes: The Holocene record of Lago dell'Accesa (Tuscany, Italy). Quaternary Science Reviews 27(11): 1181-1196.

Vannière B, Power MJ, Roberts N et al. (2011) Circum-Mediterranean fire activity and climate changes during the midHolocene environmental transition (8500-2500 cal. BP). The Holocene 21(1): 53-73.

Venables WN, Smith DM and R Core Team (2018) An introduction to $R$. Notes on R: A Programming Environment for Data Analysis and Graphics. Version 3.4.4. R Foundation.

Vogiatzakis IN, Mannion AM and Sarris D (2016) Mediterranean island biodiversity and climate change: The last 10,000 years and the future. Biodiversity and Conservation 25(13): 2597-2627.

Weng C, Hooghiemstra H and Duivenvoorden JF (2006) Challenges in estimating past plant diversity from fossil pollen data: Statistical assessment, problems, and possible solutions. Diversity and Distributions 12(3): 310-318.

Whitlock C and Larsen C (2002) Charcoal as a fire proxy. In: Smol JP, Birks HJB, Last WM et al. (eds) Tracking Environmental Change Using Lake Sediments. New York: Springer, pp. 75-97.

Wick L, Lemcke G and Sturm M (2003) Evidence of Lateglacial and Holocene climatic change and human impact in eastern Anatolia: High-resolution pollen, charcoal, isotopic and geochemical records from the laminated sediments of Lake Van, Turkey. The Holocene 13(5): 665-675. 